\title{
The effect of fermentable nitrogen availability on in vitro gas production and degradability of NDF
}

\author{
S. Nagadi, M. Herrero, N.S. Jessop* \\ Institute of Ecology and Resource Management, The University of Edinburgh, West Mains Road, \\ Edinburgh EH9 3JG, UK
}

Received 2 December 1999; received in revised form 28 March 2000; accepted 21 July 2000

\begin{abstract}
Effects of harvesting ruminal micro-organisms from ruminal fluid on patterns of gas production were investigated in experiment 1 by incubating $200 \mathrm{mg}$ DM of pure cellulose, oatfeed, ryegrass, cocksfoot, wet and dry season kikuyu grasses with either diluted ruminal fluid or harvested ruminal bacteria. Gas production degradability parameters obtained from fitting the data to the model $\mathrm{Gas}=B\left(1-\exp ^{-C(t-\mathrm{Lag})}\right)$ after correcting gas volumes for the fermentation of soluble material did not differ between these two treatments. In experiment 2 , the effect of ammonia concentration on the digestibility and gas production degradability parameters of NDF prepared from cellulose, guinea, star grass, Brachiaria decumbens and wet season kikuyu grass was studied using harvested ruminal bacteria as the inoculant. An ammonia concentration of $25 \mathrm{mg} \mathrm{N} / \mathrm{l}$ was sufficient to enable the maximum digestibility of NDF whilst one of between 50 and $100 \mathrm{mg} \mathrm{N} / \mathrm{l}$, depending on the availability of fermentable NDF, was necessary to achieve the potential rate of NDF fermentation. (C) 2000 Elsevier Science B.V. All rights reserved.
\end{abstract}

Keywords: Gas production; Protein-energy interactions; NDF fermentation

\section{Introduction}

Many factors influence the rate of fermentation of feeds. These include intrinsic characteristics of the carbohydrate fraction, such as the proportion of starch or cellulose and the extent of lignification of the cell wall. An important extrinsic factor is the supply of fermentable nitrogen required by micro-organisms to enable them to synthesise cellular constituents such as proteins and nucleic acids required for growth.

\footnotetext{
*Corresponding author. Tel.: +44-131-5354141; fax: +44-131-6672601.

E-mail address: neil.jessop@ed.ac.uk (N.S. Jessop).
} 
The simplest form of fermentable nitrogen is ammonia, which is often preferred by micro-organisms (Hungate, 1966). Many studies have looked at the effect of the ruminal ammonia concentration on feed degradation, microbial protein synthesis and microbial outflow. Based on in vivo studies, Hume et al. (1970) reported that the ammonia concentration at which microbial synthesis of protein was maximal was $88 \mathrm{mg} \mathrm{N} / \mathrm{l}$ but that the flow of microbial protein from the rumen was highest with an ammonia concentration of $133 \mathrm{mg} \mathrm{N} / \mathrm{l}$. Allen and Miller (1976) found that the greatest flows of non-ammonia nitrogen through the abomasum were achieved when the ammonia concentration in the rumen was between 160 and $220 \mathrm{mg} \mathrm{N} / 1$. Miller (1973) recommended $289 \mathrm{mg}$ ammonia $\mathrm{N} / 1$ to optimise intake and microbial outflow, whereas Mehrez et al. (1977), using an in situ method, found that an ammonia concentration of $200 \mathrm{mg} \mathrm{N} / \mathrm{l}$ was required to obtain the maximum rate of disappearance of barley DM in sheep. Similarly, Wallace (1979) observed that increased in situ DM and CP degradation rates of barley grain were accompanied by increased bacterial growth when rumen ammonia concentration was increased from 97 to $214 \mathrm{mg} \mathrm{N} / \mathrm{l}$. Krebs and Leng (1984) found that the rate of in situ degradability of cotton wool was enhanced with increasing levels of rumen ammonia up to $210 \mathrm{mg} \mathrm{N} / \mathrm{l}$ but that levels of $50 \mathrm{mg} \mathrm{N} / \mathrm{l}$ were sufficient to maximise the rate of disappearance of oaten chaff. Boniface et al. (1986) found that the maximum rate of disappearance (in situ) of grass hay was observed at ammonia levels of about $50 \mathrm{mg} \mathrm{N} / \mathrm{l}$. Erdman et al. (1986) reported that in situ degradation rates plateaued at ammonia concentration in excess of $200 \mathrm{mg} \mathrm{N} / \mathrm{l}$ and concluded that the nitrogen requirement to achieve maximum rate of degradation of DM or NDF was dependent on the potential degradability of feed.

In vitro techniques have also been used. Oosting et al. (1989), using a technique based on Tilley and Terry (1963), noted that $100 \mathrm{mg}$ N/l was required for maximum degradation of feed DM or OM. Recently, Dryhurst and Wood (1998), using a gas production technique based on Theodorou et al. (1994) studied the effect of nitrogen concentration on gas production dynamics of barley straw. They concluded that a minimum ammonia concentration of about $80 \mathrm{mg} \mathrm{N} / \mathrm{l}$ was needed to achieve maximum degradation of carbohydrate by rumen microbes. However, this nitrogen concentration may underestimate the true concentration of nitrogen available to microbes since the contribution of ammonia in the inoculum was about $28 \mathrm{mg} \mathrm{N} / \mathrm{l}$. Satter and Slyter (1974), using continuous culture fermenters, found that the limiting ammonia concentration was about $20 \mathrm{mg} / \mathrm{l}$ but suggested that the ammonia concentration of $50 \mathrm{mg} \mathrm{N} / \mathrm{l}$ was a practical requirement for maximal microbial growth. Schaefer et al. (1980), using pure cultures, reported a requirement for a concentration of ammonia of $14 \mathrm{mg} \mathrm{N} / 1$ to achieve $95 \%$ of maximal microbial growth rate.

General guidelines on the level of ammonia concentration needed by rumen microbes to maximise the microbial growth and fermentation process therefore range from $20 \mathrm{mg} \mathrm{N} / 1$ (Satter and Slyter, 1974; Boniface et al., 1986) to over $200 \mathrm{mg}$ N/l (Miller, 1973; Mehrez et al., 1977; Erdman et al., 1986).

In the above reports the endogenous nitrogen supplied by the animal, inoculum or substrate were not controlled. Thus, the nitrogen concentrations indicated may underestimate true nitrogen availability to the rumen microbes. The objectives of this work were (1) to study the effect of harvesting ruminal micro-organisms to remove the 
fermentable nitrogen present in ruminal fluid on the gas production profiles, and (2) to study the effect of fermentable nitrogen availability on NDF degradability using harvested ruminal micro-organisms.

\section{Materials and methods}

\subsection{Animals and diet}

Two ruminally fistulated Suffolk sheep fed $750 \mathrm{~g}$ of sheep pellets (338 $\mathrm{g}$ of NDF/kg $\mathrm{DM}$ and $175 \mathrm{~g}$ of CP/kg DM) and $250 \mathrm{~g}$ of grass nuts (345 $\mathrm{g}$ of NDF/ $/ \mathrm{kg} \mathrm{DM}$ and $150 \mathrm{~g}$ of $\mathrm{CP} / \mathrm{kg} \mathrm{DM}$ ) twice a day at 8.00 and $17.00 \mathrm{~h}$ were used. Water was available ad libitum.

\subsection{Inoculum preparation}

A sample of rumen contents containing both solid and liquid material was taken before the morning feeding and collected in a pre-warmed vacuum flask. In the laboratory, ruminal fluid was filtered through two layers of muslin cloth with the solid material being squeezed lightly. The microbial activity of the strained ruminal fluid samples was determined by measuring the bacterial DM indirectly from the absorbance of diluted ruminal fluid at $600 \mathrm{~nm}$ (Wells and Russell, 1996). The strained ruminal fluid was mixed with anaerobic medium (Menke and Steingass, 1988) before or after centrifugation according to the design of each experiment. Once prepared, the suspension of microorganisms was maintained at $39^{\circ} \mathrm{C}$ with $\mathrm{CO}_{2}$ bubbling through it for approximately $20 \mathrm{~min}$ before addition to the gas fermentation syringes.

\subsection{Experimental treatments}

\subsubsection{Experiment 1}

This experiment was designed to compare the gas production profile of harvested rumen micro-organisms with that of strained ruminal fluid. In six runs, the strained ruminal liquor $(21)$ was divided into two portions. The first portion was mixed with anaerobic medium (1:2) and kept at $39^{\circ} \mathrm{C}$ with $\mathrm{CO}_{2}$ bubbling through it until the time of incubation whilst the second portion was immediately centrifuged at $1000 \times g$ for 5 min at $30^{\circ} \mathrm{C}$ to harvest the protozoa and fungi (Henning et al., 1991). The pellet was washed with $50 \mathrm{ml}$ of the anaerobic media and kept at $39^{\circ} \mathrm{C}$ while the supernatant was recentrifuged at $26,000 \times g$ for $15 \mathrm{~min}$ at $30^{\circ} \mathrm{C}$ to harvest bacteria (Henning et al., 1991; Pell and Schofield, 1993). The supernatant was discarded and the bacterial pellet was mixed with $50 \mathrm{ml}$ of media. The pellets were combined and made up to the original volume with anaerobic medium. This suspension of washed micro-organisms was diluted with anaerobic medium (1:2) before addition to gas fermentation syringes. Gas production was measured in the absence of substrate and from the incubation of $200 \mathrm{mg}$ DM $\alpha$-cellulose (Sigma, Chemical Co. Ltd., Poole, Dorset, UK), oatfeed, ryegrass (Lolium perenne), cocksfoot (Dactyylis glomerata), as well as wet and dry season kikuyu grasses (Pennisetum clandestinum) in $100 \mathrm{ml}$ glass syringes (Fortuna, 
Table 1

Chemical composition of forage samples

\begin{tabular}{lccc}
\hline Forage sample & $\mathrm{CP}\left(\mathrm{g} \mathrm{kg}^{-1} \mathrm{DM}\right)$ & $\mathrm{NDF}\left(\mathrm{g} \mathrm{kg}^{-1} \mathrm{DM}\right)$ & $\left.\mathrm{Ash}_{(\mathrm{g} \mathrm{kg}}^{-1} \mathrm{DM}\right)$ \\
\hline Ryegrass & 193 & 476 & 82 \\
Kikuyu (wet season) & 259 & 534 & 127 \\
Kikuyu (dry season) & 60 & 751 & 103 \\
Cocksfoot & 91 & 508 & 73 \\
Oatfeed & 87 & 271 & 39 \\
Star grass & 43 & 755 & 96 \\
B. decumbens & 129 & 592 & 122 \\
Guinea grass & 96 & 626 & 118 \\
\hline
\end{tabular}

Germany) separately using suspensions of strained ruminal liquor and washed ruminal micro-organisms. Forage samples were analysed for neutral detergent fibre (NDF) using a modified micro technique (Pell and Schofield, 1993) in which the detergent-insoluble residue is not treated with amylase or ashed. Crude protein $(\mathrm{CP})$ and ash were determined using standard techniques (AOAC, 1980) (Table 1).

\subsubsection{Experiment 2}

This experiment was designed to study the influence of nitrogen availability on the gas production degradability parameters. Strained ruminal fluid (1 l) was divided into five portions and immediately centrifuged to remove the fermentable $\mathrm{N}$ from the inoculum as described in experiment 1 . The pellets from both the initial and final centrifugation of each portion were gently resuspended in anaerobic medium and made up to the original volume. Each portion of washed micro-organisms were then diluted with anaerobic medium (1:2) for addition to the gas production syringes. Nitrogen was added as ammonium bicarbonate to give the following concentrations of $0,25,50,100$ and $200 \mathrm{mg} \mathrm{N} \mathrm{I}^{-1}$ in the final suspension of washed micro-organisms. To maintain a constant level of bicarbonate in the medium, the difference between the standard amount of ammonium bicarbonate and the amount needed to yield the desired concentrations was replaced with sodium bicarbonate. The ammonia concentration $(\mathrm{mg} \mathrm{N} / \mathrm{l})$ of strained ruminal fluid, harvested rumen micro-organisms, anaerobic media and final cultures of harvested rumen micro-organisms and media was determined using an ammonia electrode. The ammonia concentrations achieved in the final microbial suspensions were $5.1,29.9,54.5,105.0$ and $204.8 \mathrm{mg} \mathrm{N} / 1$.

About $2 \mathrm{~g}$ of NDF from guinea grass (Panicum maximum), star grass (Cydon nlenfluensis), Brachiaria grass (Brachiaria decumbens) and wet season kikuyu grass were prepared by refluxing each forage with neutral detergent solution (without sodium sulfite) according to the method of Van Soest and Robertson (1985) as described by Blümmel and Becker (1997). After refluxing, the NDF was recovered on a sintered glass crucible and rinsed with distilled water fifteen times. For each ammonium concentration, gas production was measured in the absence of substrate and from the incubation of $200 \mathrm{mg}$ of dry NDF of the above forage samples and $\alpha$-cellulose in $100 \mathrm{ml}$ glass syringes (Fortuna, Germany). Each combination of ammonium concentration and substrate was replicated four times. NDF residues were collected at the end of the incubations for estimation of NDF 
digestibility (NDFD) using a modified micro technique (Pell and Schofield, 1993). The contents of each syringe were emptied into $100 \mathrm{ml}$ medical flat bottles and washed three times with $5 \mathrm{ml}$ of ND solution, the washings being added to the appropriate bottle.

\subsection{Gas production measurements and analytical procedures}

Measurement of in vitro gas production was completed as described by Jessop and Herrero (1996). The cumulative gas production for each syringe was recorded at 1, 2, 3, 4, $5,6,8 \mathrm{~h}$; thereafter every $4 \mathrm{~h}$ until $60 \mathrm{~h}$, and then at 72, 84, 96 and $120 \mathrm{~h}$, and were corrected for gas produced in the absence of substrate. In experiment 1, where soluble carbohydrate was present for some substrates, the gas produced at $4 \mathrm{~h}$ was assumed to be a measure of soluble carbohydrate $(A)$ and cumulative gas volumes were further corrected for this (Herrero and Jessop, 1996). The resulting pattern of gas production was analysed by fitting of the model Gas $=B\left(1-\exp ^{-C(t-\mathrm{Lag})}\right)$ (Krishnamoorthy et al., 1991) using the Marquart algorithm as implemented by GraFit (Leatherbarrow, 1992). This model was chosen because of the biological relevance of its parameters, where $B$ is the asymptotic gas production from the fermentation of NDF $(\mathrm{ml}), C$ the fractional rate of gas production $\left(\mathrm{h}^{-1}\right), t$ is time (h) and Lag the lag phase before the fermentation of NDF begins $(\mathrm{h})$.

\subsection{Statistical analysis}

Paired $T$ tests were used to compare the degradability parameters of feed between harvested and unharvested ruminal micro-organisms in experiment 1. A general linear model was used to compare effects of ammonia concentration and substrate, and their interactions, for both gas production parameters and NDFD in experiment 2. The statistical package Minitab (1993) was used for these purposes. Least significant differences were calculated from the standard error of the differences between means.

\section{Results}

\subsection{Effect of harvesting ruminal micro-organisms on gas production dynamics}

The method used to harvest micro-organisms did not appear to alter the microbial concentration of the inoculant as judged by the volume of gas produced from syringes with no added substrate; these averaged $21.3 \mathrm{ml}$ and did not differ between experiments or with ammonia concentration. The estimated parameter values for in vitro gas production dynamics of cellulose, wet and dry season kikuyu grass, ryegrass, cocksfoot, and oatfeed incubated either in harvested or unharvested ruminal liquor microbes are in Table 2. There were no differences due to harvesting of ruminal micro-organisms.

\subsection{The influence of nitrogen concentration on gas production dynamics and NDFD}

The NDF digestibility (NDFD) and the estimated gas production degradability parameters of the NDF fractions of cellulose, wet season kikuyu grass, B. decumbens, 
Table 2

Gas production degradability parameters of cellulose, wet and dry season kikuyu grass, ryegrass, cocksfoot and oatfeed incubated with either harvested or unharvested ruminal fluid micro-organisms ${ }^{\mathrm{a}}$

\begin{tabular}{|c|c|c|c|c|}
\hline \multicolumn{2}{|c|}{ Gas production degradability parameters ${ }^{b}$} & \multicolumn{2}{|c|}{ Ruminal fluid micro-organisms } & \multirow[t]{2}{*}{ S.E.M. ${ }^{\mathrm{c}}$} \\
\hline & & Harvested & Unharvested & \\
\hline \multirow[t]{4}{*}{ Cellulose } & $A(\mathrm{ml})$ & 0 & 0 & \\
\hline & $B(\mathrm{ml})$ & 90.6 & 91.3 & 0.67 \\
\hline & $C\left(\mathrm{~h}^{-1}\right)$ & 0.097 & 0.102 & 0.0035 \\
\hline & Lag (h) & 4.7 & 4.5 & 0.22 \\
\hline \multirow[t]{4}{*}{ Kikuyu (wet season) } & $A(\mathrm{ml})$ & 8.6 & 8.7 & 0.11 \\
\hline & $B(\mathrm{ml})$ & 38.6 & 39.1 & 0.67 \\
\hline & $C\left(\mathrm{~h}^{-1}\right)$ & 0.056 & 0.058 & 0.0035 \\
\hline & Lag (h) & 5.4 & 5.2 & 0.22 \\
\hline \multirow[t]{4}{*}{ Kikuyu (dry season) } & $A(\mathrm{ml})$ & 5.2 & 5.6 & 0.11 \\
\hline & $B(\mathrm{ml})$ & 29.5 & 32.6 & 0.67 \\
\hline & $C\left(\mathrm{~h}^{-1}\right)$ & 0.044 & 0.045 & 0.0035 \\
\hline & Lag (h) & 5.7 & 5.7 & 0.22 \\
\hline \multirow[t]{4}{*}{ Ryegrass } & $A(\mathrm{ml})$ & 19.6 & 19.2 & 0.11 \\
\hline & $B(\mathrm{ml})$ & 43.9 & 41.5 & 0.67 \\
\hline & $C\left(\mathrm{~h}^{-1}\right)$ & 0.069 & 0.066 & 0.0035 \\
\hline & Lag (h) & 3.7 & 3.6 & 0.22 \\
\hline \multirow[t]{4}{*}{ Cocksfoot } & $A(\mathrm{ml})$ & 12.1 & 12.3 & 0.11 \\
\hline & $B(\mathrm{ml})$ & 39.4 & 39.4 & 0.67 \\
\hline & $C\left(\mathrm{~h}^{-1}\right)$ & 0.057 & 0.061 & 0.0035 \\
\hline & Lag (h) & 4.1 & 3.9 & 0.22 \\
\hline \multirow[t]{4}{*}{ Oatfeed } & $A(\mathrm{ml})$ & 9.1 & 9.3 & 0.11 \\
\hline & $B(\mathrm{ml})$ & 27.5 & 27.7 & 0.67 \\
\hline & $C\left(\mathrm{~h}^{-1}\right)$ & 0.046 & 0.048 & 0.0035 \\
\hline & Lag (h) & 3.7 & 3.8 & 0.22 \\
\hline
\end{tabular}

${ }^{\text {a }}$ Each value is a mean of six replicates.

${ }^{\mathrm{b}} A$ is the gas produced at $4 \mathrm{~h}$ and $B, C$ and Lag are parameters obtained by fitting the gas production data, corrected for $A$, to the equation: Gas $=B\left(1-\exp ^{-C(t-\mathrm{Lag})}\right)$ where $B$ is the asymptotic gas production from fermentation of NDF, $C$ the fractional rate of gas production and Lag is the time taken for gas production from $B$ to begin.

${ }^{c}$ There were no differences in parameters due to method of preparation of micro-organisms.

guinea grass and star grass incubated with harvested ruminal micro-organisms at different nitrogen (ammonium bicarbonate) concentrations (0, 25, 50, 100 and $200 \mathrm{mg} \mathrm{N} / \mathrm{l}$ ) are in Table 3. There were differences in parameters between feed sources and, in general, the overall influence of increasing the level of nitrogen concentration from 0 to $200 \mathrm{mg} \mathrm{N} / \mathrm{l}$ was to increase digestibility and rate of fermentation and to decrease the lag. The response to $\mathrm{NH}_{3}$ concentration with particular substrates varied for both the fractional rate and lag.

The asymptotic gas production from the fermentation of NDF $(B)$ and NDF digestibility of cellulose, wet season kikuyu grass, $B$. decumbens and guinea grass incubated in nitrogen free medium were significantly $(P<0.05)$ lower than those incubated in 25, 50, 100 and $200 \mathrm{mg} \mathrm{N} / 1$, whereas the asymptotic gas production $(B)$ and 
Table 3

Fitted degradability parameters of NDF and NDFD of cellulose, guinea, star, B. decumbens and wet season kikuyu incubated with harvested ruminal fluid micro-organisms at different ammonium concentrations (mg N/l $)^{\mathrm{a}}$

\begin{tabular}{|c|c|c|c|c|c|}
\hline \multirow[t]{2}{*}{ Feed sample } & \multirow{2}{*}{$\begin{array}{l}\text { Ammonium } \\
\text { concentration } \\
(\mathrm{mg} \mathrm{N} / \mathrm{l})\end{array}$} & \multicolumn{4}{|c|}{ Gas production degradability parameters ${ }^{b}$} \\
\hline & & $B(\mathrm{ml})$ & $C\left(\mathrm{~h}^{-1}\right)$ & $\operatorname{Lag}(\mathrm{h})$ & NDFD $\left(\mathrm{g} \mathrm{kg}^{-1} \mathrm{DM}\right)$ \\
\hline \multirow[t]{5}{*}{ Cellulose } & 0 & $80.1 \mathrm{a}$ & $0.051 \mathrm{a}$ & $8.2 \mathrm{a}$ & 978 a \\
\hline & 25 & $89.9 \mathrm{~b}$ & $0.077 \mathrm{~b}$ & $6.7 \mathrm{~b}$ & $999 \mathrm{~b}$ \\
\hline & 50 & $90.2 \mathrm{~b}$ & $0.089 \mathrm{c}$ & $5.3 \mathrm{c}$ & $1000 \mathrm{~b}$ \\
\hline & 100 & $91.5 \mathrm{~b}$ & $0.098 \mathrm{~d}$ & $4.6 \mathrm{~d}$ & $1000 \mathrm{~b}$ \\
\hline & 200 & $90.9 \mathrm{~b}$ & $0.101 \mathrm{~d}$ & $4.4 \mathrm{~d}$ & $1000 \mathrm{~b}$ \\
\hline \multirow[t]{5}{*}{ Kikuyu (wet season) } & 0 & $60.2 \mathrm{a}$ & $0.043 \mathrm{a}$ & $8.7 \mathrm{a}$ & $628 \mathrm{a}$ \\
\hline & 25 & $66.7 \mathrm{~b}$ & $0.048 \mathrm{~b}$ & $7.3 \mathrm{~b}$ & $703 \mathrm{~b}$ \\
\hline & 50 & $67.3 \mathrm{~b}$ & $0.052 \mathrm{c}$ & $6.1 \mathrm{c}$ & $711 \mathrm{~b}$ \\
\hline & 100 & $67.9 \mathrm{~b}$ & $0.057 \mathrm{~d}$ & $5.0 \mathrm{~d}$ & $715 \mathrm{~b}$ \\
\hline & 200 & $68.6 \mathrm{~b}$ & $0.059 \mathrm{~d}$ & $4.9 \mathrm{~d}$ & $728 \mathrm{~b}$ \\
\hline \multirow[t]{5}{*}{ B. decumbens } & 0 & $58.8 \mathrm{a}$ & $0.040 \mathrm{a}$ & $9.1 \mathrm{a}$ & $617 \mathrm{a}$ \\
\hline & 25 & $64.4 \mathrm{~b}$ & $0.046 \mathrm{~b}$ & $7.8 \mathrm{~b}$ & $680 \mathrm{~b}$ \\
\hline & 50 & $65.2 \mathrm{~b}$ & $0.051 \mathrm{c}$ & $6.5 \mathrm{c}$ & $686 \mathrm{~b}$ \\
\hline & 100 & $65.9 \mathrm{~b}$ & $0.056 \mathrm{~d}$ & $5.0 \mathrm{~d}$ & $698 \mathrm{~b}$ \\
\hline & 200 & $66.1 \mathrm{~b}$ & $0.058 \mathrm{~d}$ & $4.8 \mathrm{~d}$ & $707 \mathrm{~b}$ \\
\hline \multirow[t]{5}{*}{ Guinea grass } & 0 & $50.1 \mathrm{a}$ & $0.032 \mathrm{a}$ & $9.3 \mathrm{a}$ & $524 \mathrm{a}$ \\
\hline & 25 & $56.4 \mathrm{~b}$ & $0.037 \mathrm{~b}$ & $7.2 \mathrm{~b}$ & $604 \mathrm{~b}$ \\
\hline & 50 & $56.5 \mathrm{~b}$ & $0.042 \mathrm{c}$ & $5.6 \mathrm{c}$ & $609 \mathrm{~b}$ \\
\hline & 100 & $56.7 \mathrm{~b}$ & $0.048 \mathrm{~d}$ & $5.3 \mathrm{c}$ & $618 \mathrm{~b}$ \\
\hline & 200 & $58.5 \mathrm{~b}$ & $0.049 \mathrm{~d}$ & $5.1 \mathrm{c}$ & $634 \mathrm{~b}$ \\
\hline \multirow[t]{5}{*}{ Star grass } & 0 & $38.5 \mathrm{a}$ & $0.021 \mathrm{a}$ & $11.4 \mathrm{a}$ & $408 \mathrm{a}$ \\
\hline & 25 & 39.7 a & $0.026 \mathrm{~b}$ & $10.3 \mathrm{~b}$ & $419 \mathrm{a}$ \\
\hline & 50 & $40.5 \mathrm{a}$ & $0.030 \mathrm{c}$ & $8.4 \mathrm{c}$ & $430 \mathrm{a}$ \\
\hline & 100 & $40.8 \mathrm{a}$ & $0.032 \mathrm{c}$ & $8.0 \mathrm{c}$ & 443 a \\
\hline & 200 & $40.6 \mathrm{a}$ & $0.030 \mathrm{c}$ & $7.9 \mathrm{c}$ & $441 \mathrm{a}$ \\
\hline S.E.D. & & 1.28 & 0.0017 & 0.42 & 22.7 \\
\hline Effect of ammonia concentration & & $*$ & $*$ & $*$ & $*$ \\
\hline Effect of feed & & $*$ & $*$ & $*$ & * \\
\hline Ammonia concentration $\times$ Feed & & ns & $*$ & $*$ & ns \\
\hline
\end{tabular}

\footnotetext{
${ }^{a}$ Each value is a mean of four replicates. For each feed sample, means with different letters within the same
} column are significantly different $(P<0.05)$.

${ }^{\mathrm{b}} B, C$ and Lag are parameters obtained by fitting the gas production data to the equation: Gas $=B\left(1-\exp ^{-C(t-\mathrm{Lag})}\right)$ where $B$ is the asymptotic gas production from fermentation of NDF, $C$ the fractional rate of gas production and Lag is the time taken for gas production from $B$ to begin.

${ }^{*} P<0.05$; ns: $P>0.05$.

NDFD of star grass were not influenced by the availability of N. However, there were no differences in asymptotic gas production from the fermentation of NDF $(B)$ and NDFD of cellulose, wet season kikuyu grass, $B$. decumbens and guinea grass when the nitrogen concentration increased from 25 to $200 \mathrm{mg} \mathrm{N} / 1$.

The rate of gas production from fermentation of the NDF $(C)$ of cellulose, wet season kikuyu grass, $B$. decumbens and guinea grass increased $(P<0.05)$ as $\mathrm{N}$ concentration 
increased from 0 to $100 \mathrm{mg} / \mathrm{l}$, after which there was no response to $\mathrm{N}$ concentration. In contrast, the rate of gas production from fermentation of the NDF of star grass increased $(P<0.05)$ until the $\mathrm{N}$ concentration reached $50 \mathrm{mg} \mathrm{N} / \mathrm{l}$, above which no further response was seen.

The lag phase before the fermentation of NDF began in guinea and star grass decreased $(P<0.05)$ as the $\mathrm{N}$ concentration increased from 0 to $50 \mathrm{mg} \mathrm{N} / 1$ but thereafter there was no effect of $\mathrm{N}$ concentration. The lag for cellulose, wet season kikuyu grass and $B$. decumbens appeared to be more sensitive to nitrogen concentration, declining $(P<0.05)$ until the concentration of nitrogen reached $100 \mathrm{mg} \mathrm{N} / \mathrm{l}$.

\section{Discussion}

\subsection{The effect of harvesting ruminal microbes on gas production dynamics}

In order to investigate the effect of nutrient availability on degradation characteristics of feeds, the potential endogenous supply of the specific nutrient under study should be considered. For the in vitro gas production technique, endogenous supplies of fermentable nitrogen will be present in strained ruminal fluid. Results indicate that microbes can be harvested from ruminal fluid without altering the gas production degradability parameters using the centrifugation speeds recommended by Henning et al. (1991). This increases the potential use of the in vitro gas production technique by enabling more precise control of the nature of the microbial inoculant. It also permits microbial concentration to be controlled, variation in which has been shown to influence the pattern of gas production observed (Jessop and Herrero, 1998).

\subsection{Influence of nitrogen concentration on gas production dynamics and NDFD}

The primary objective of this work was to study the effect of $\mathrm{N}$ availability on the degradability and digestibility of NDF, and results show that each was sensitive to the availability of N. A change in NDFD might be the cause of differences in the asymptotic gas production from the fermentation of NDF $(\mathrm{ml})$ between feed samples incubated either in zero ammonia concentration (the clarified inoculum contribution was about $4.9 \mathrm{mg} \mathrm{N} /$ 1) or at another ammonia concentration (25, 50, 100 and $200 \mathrm{mg} \mathrm{N} / \mathrm{l})$. This could be due to a deficiency of nutrient supply to the microbes in the form of ammonia which would reduce the efficiency of rumen microbial growth, and so the maximal fermentation achieved. Dryhurst and Wood (1998), found that ammonia concentrations of 0, 20, 40, 80, 120 and $165 \mathrm{mg} \mathrm{N} / \mathrm{l}$ did not alter total gas production and DMD of barley straw when the incubation time was extended to $166 \mathrm{~h}$. However, the $\mathrm{N}$ concentration in their study was an underestimate of the true concentration of $\mathrm{N}$ available to the microbes, since fermentable $\mathrm{N}$ would have been available from the inoculant (i.e. stated as $28 \mathrm{mg} \mathrm{N} / \mathrm{l}$ ) and from the feed source.

Stoichiometric relationships have shown that about $0.47 \mathrm{ml}$ of gas should be produced per mg of NDF fermented (Wolin, 1960; Herrero and Jessop, 1996). Using the NDFD value (Table 3 ) of pure cellulose incubated at an ammonia concentration of zero to 
estimate total gas predicted to be produced from the fermentation of NDF, it can be calculated that about $92 \mathrm{ml}$ gas should be produced from $200 \mathrm{mg}$ DM cellulose with a digestibility of $97.8 \%$ whereas the actual total gas observed was $80.1 \mathrm{ml}$. It may be that NDFD of pure cellulose was overestimated due to a reduction in particle size over the course of the incubation to the extent where some undegraded material was able to pass through the pores of the sintered glass crucible and assumed to have been fermented. Thus, care should be taken when using a modified micro technique (Pell and Schofield, 1993) to measure the NDFD of feed.

Results also indicate that the fractional rate of gas production for cellulose, $B$. decumbens, guinea and wet season kikuyu grass increased as the ammonia concentration increased up to a value of $100 \mathrm{mg} \mathrm{N} / \mathrm{l}$, in agreement with work in vivo (Hume et al., 1970) and in vitro (Tilley and Terry, 1963; Oosting et al., 1989). It is also consistent with the study of Dryhurst and Wood (1998), using an in vitro gas production technique based on Theodorou et al. (1994) if the contribution of $\mathrm{N}$ supplied by the inoculum was considered. For star grass, which has the lowest fermentation rate of the substrates used, ' $C$ ' increased only up to an ammonia concentration of $50 \mathrm{mg} \mathrm{N} / \mathrm{l}$ and NDFD was not sensitive to ammonia concentration. These responses were similar to values reported in vitro (Satter and Slyter, 1974) and in situ (Krebs and Leng, 1984, using for oaten chaff; and Boniface et al., 1986).

The different responses between substrates in fractional rates and extents of fermentation to the availability of $\mathrm{N}$ could be related to the relationship between carbohydrate availability and the $\mathrm{N}$ requirement as suggested by Erdman et al. (1986). The effect of the availability of both $\mathrm{N}$ and digestible NDF $(\mathrm{dNDF}(\mathrm{NDF} \times \mathrm{NDFD}))$ on the rate of gas production is in Fig. 1. It represents interpolation from the data derived and illustrates the interaction between ammonia concentrations and feed samples for the rate of gas production. Clearly, the rate of gas production was dependent on the availability of both $\mathrm{N}$ and fermentable carbohydrate. As dNDF increased, so a higher level of fermentable nitrogen availability was required, in agreement with Erdman et al. (1986).

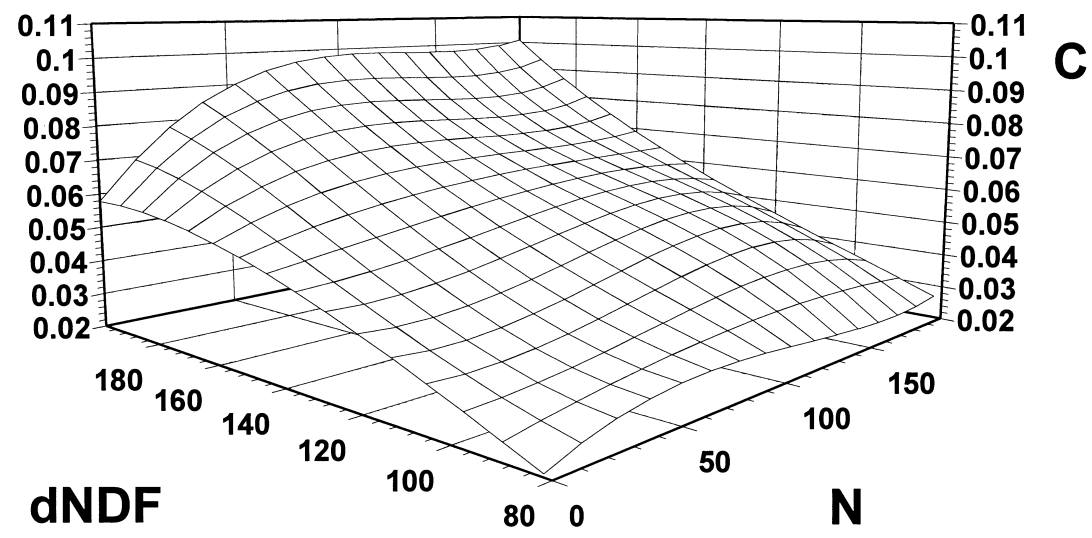

Fig. 1. The effect of nitrogen $(\mathrm{N}(\mathrm{mg} / \mathrm{l}))$ and digestible NDF (dNDF (mg/200 mg NDF)) availability on the rate of gas production $\left(C\left(\mathrm{~h}^{-1}\right)\right)$. 
An ammonia concentration of $100 \mathrm{mg}$ N/l was sufficient to enable a fractional rate of cellulose fermentation of $0.1 \mathrm{~h}^{-1}$, which is the potential rate of fermentation of this substrate (Weimer, 1996).

Responses in the extent of disappearance of barley DM in situ (Mehrez et al., 1977) or effective degradability of feeds (Erdman et al., 1986) have been reported to concentrations of ruminal ammonia in excess of $100 \mathrm{mg} \mathrm{N} / \mathrm{l}$. In these cases the potential rate of degradation of the feedstuff was greater than those in this study due to the high starch content of the feeds. The high starch content may also have favoured the dominance of a different microbial population (amylolytic versus cellulolytic) to that in this study.

Correcting the balance of $\mathrm{N}$ and fermentable carbohydrate supply to rumen microbes ensures that the maximal rate of fermentation is achieved and can improve the degradability of forages (Leng, 1990). The current studies indicate that the in vitro gas production technique can be used for such investigations.

\section{Conclusions}

The results of this study indicated that micro-organisms can be harvested from ruminal fluid without altering the subsequent pattern of gas production from a variety of substrates. This enables the influence of substances present in ruminal fluid to be reduced. Using this procedure, it was shown that the extent of fermentation of NDF generally increased as ammonia concentration increased from 0 to $25 \mathrm{mg} \mathrm{N} / \mathrm{l}$, but not thereafter. However, the rate of NDF fermentation increased as the ammonia concentration increased to between 50 and $100 \mathrm{mg} \mathrm{N} / \mathrm{l}$ depending on the quantity of digestible NDF present in the substrate. This demonstrates that protein-energy interactions can be studied using the in vitro gas production technique.

\section{Acknowledgements}

We are grateful for the skilled technical assistance of G.F. Allan and the statistical advice of Mr. E.A. Hunter, Biomathematics and Statistics, Scotland.

\section{References}

Allen, S.A., Miller, E.L., 1976. Determination of nitrogen requirement fir microbial growth from the effect of urea supplementation of a low $\mathrm{N}$ diet on abomasal $\mathrm{N}$ flow and $\mathrm{N}$ recycling in wethers and lambs. Br. J. Nutr. $36,535-568$.

AOAC (1980). Official Methods of Analysis, 13th edition. AOAC, Washington DC.

Blümmel, M., Becker, K., 1997. The degradation characteristics of 54 roughages and roughage NDF as described by in vitro gas production and their relationship to voluntary feed intake. Br. J. Nutr. 77, 757-768.

Boniface, A.N., Murray, R.M., Hogan, J.P., 1986. Optimum level of ammonia in the rumen liquor of cattle fed tropical pasture hay. Proc. Aust. Soc. Anim. Prod. 16, 151-154.

Dryhurst, N., Wood, C.D., 1998. The effect of nitrogen source and concentration on in vitro gas production using rumen micro-organisms. Anim. Feed Sci. Technol. 71, 131-143. 
Erdman, R.A., Proctor, G.H., Vandersall, J.H., 1986. Effect of rumen ammonia concentration on in situ rate and extent of digestion of feed stuffs. J. Dairy Sci. 69, 2312-2320.

Henning, P.H., Steyn, D.G., Meissner, H.H., 1991. The effect of energy and nitrogen supply pattern on rumen bacterial growth in vitro. Anim. Prod. 53, 165-175.

Herrero, M., Jessop, N.S., 1996. Relationship between in vitro gas production and neutral detergent fibre disappearance in three tropical grasses. Anim. Sci. 62, 682.

Hume, I.D., Moir, R.G., Somers, M., 1970. Synthesis of microbial protein in the rumen. I. Influence of the level of nitrogen intake. Aust. J. Agric. Res. 21, 283-296.

Hungate, R.E., 1966. The Rumen and its Microbes. Academic Press, New York.

Jessop, N.S., Herrero, M., 1996. Influence of soluble components on parameter estimation using the in vitro gas production technique. Anim. Sci. 62, 626-627.

Jessop, N.S., Herrero, M., 1998. Modelling fermentation in an in vitro gas production system: effects of microbial activity. In vitro techniques for measuring nutrient supply to ruminants. British Society of Animal Science Occasional Publication No. 22, 1998, pp. 81-84.

Krebs, G., Leng, R.A., 1984. The effect of supplementation with molasses/urea blocks on ruminal digestion. Proc. Aust. Soc. Anim. Prod. 15, 704 (abstract).

Krishnamoorthy, U., Soller, H., Steingass, H., Menke, K.H., 1991. A comparative study on rumen fermentation of energy supplements in vitro. J. Anim. Physiol. Anim. Nutr. 65, 28-35.

Leatherbarrow, R.J., 1992. GraFit Version 3. Erithacus Software Ltd., Staines, UK.

Leng, R.A., 1990. Factors affecting the utilization of "Poor-Quality" forages by ruminants particularly under tropical conditions. Nutr. Res. Rev. 3, 277-303.

Mehrez, A.Z., Ørskov, E.R., McDonald, I., 1977. Rates of rumen fermentation in relation to ammonia concentration. Br. J. Nutr. 38, 437-443.

Menke, K.H., Steingass, H., 1988. Estimation of the energetic feed value obtained from chemical analysis and in vitro gas production using rumen fluid. Anim. Res. Dev. 28, 7-55.

Miller, E.L., 1973. Evaluation of foods as sources of nitrogen and amino acids. Proc. Nutr. Soc. 32, 79-84.

Minitab, 1993. Statistical software. Release 9. Minitab Inc., Pennsylvania, USA.

Oosting, S.J., Verdonk, J.M.J.H., Spinhoven, G.G.B., 1989. Effect of supplementary urea, glucose and minerals on the in vitro degradation of low quality feeds. Asian-Aust. J. Anim. Sci. 2, 583-590.

Pell, A.N., Schofield, P., 1993. Computerised monitoring of gas production to measure forage digestion in vitro. J. Dairy Sci. 76, 1063-1073.

Satter, L.D., Slyter, L.L., 1974. Effect of ammonia concentration on rumen microbial protein production in vitro. Br. J. Nutr. 32., 194-208.

Schaefer, D.M., Davis, C.L., Bryant, M.P., 1980. Ammonia saturation constants for predominant species of rumen bacteria. J. Dairy Sci. 63, 1248-1263.

Theodorou, M.K., Williams, B.A., Dhanoa, M.S., McAllan, A.B., France, J., 1994. A simple gas production method using a pressure transducer to determine the fermentation kinetics of ruminant feeds. Anim. Feed Sci. Technol. 48, 185-197.

Tilley, J.M.A., Terry, R.A., 1963. A two-stage technique for the in vitro digestion of forage crops. J. Br. Grssl. Soc. 18, 104-111.

Van Soest, P.J., Robertson, J.B., 1985. A Laboratory Manual for Animal Science 612. Cornell University, Ithaca, NY.

Wallace, R.J., 1979. Effect of ammonia concentration on the composition, hydrolytic activity and nitrogen metabolism of the microbial flora of the rumen. J. Appl. Bact. 47, 443-445.

Weimer, P.J., 1996. Why don't rumen bacteria digest cellulose faster? J. Dairy Sci. 79, 1496-1502.

Wells, J.E., Russell, J.B., 1996. Why do many ruminal bacteria die and lyse so quickly? J. Dairy Sci. 79, 14871495.

Wolin, M.J., 1960. A theoretical rumen fermentation balance. J. Dairy Sci. 43, 1452-1459. 